\title{
Can the absence of ants interfere in the arthropods abundance on corn plants (Zea mays L. - Poaceae)?
}

\author{
Odair Santos Gossler'; Denise Lange2*, Wedson Desidério Fernandes ${ }^{3}$
}

\author{
'Federal University of Mato Grosso do Sul, Nova Andradina Campus, Nova Andradina, MS, Brazil. \\ ${ }^{2}$ Federal University of Technology - Parana, Santa Helena Campus, Santa Helena, PR, Brazil. \\ ${ }^{3}$ Federal University of Grande Dourados, Faculty of Environmental and Biological Sciences, Dourados, MS, Brazil. \\ *Corresponding author, e-mail: deniselange@yahoo.com.br
}

\begin{abstract}
Alternative methods to reduce the chemical control in monoculture have been widely assessed in order to diminish the pesticide use. Thus, the efficiency of predator arthropods who work as population controllers in many agro-ecosystems has been tested. The current study aim to verify if the presence of ants interfere in the amount of arthropod herbivores and predators on corn plants, Zea mays $L$. (Poaceae). A total of 100 plants were assessed, out of them, 50 were isolated from ants and the other 50 were not. There were 25 taxa of arthropods on corn plants, in which 14 were herbivorous and 11 predators. The ants' free access to the plants negatively influenced the Diabrotica speciosa (Germar, 1824) (Coleoptera: Chrysomelidae) amount, which is an important herbivorous plague in corn monoculture. It was also observed the greater amount of Doru sp. 1 (Dermaptera: Forficulidae) on plants containing ants. Considering the assessed plants, the presence of ants did not influenced the abundance of other arthropods. These results suggest that the ant-plant-herbivore interactions in corn monoculture is a complex system, and the presence of predatory ants in plants not always influence the presence of other arthropods.
\end{abstract}

Keywords: agro-ecosystem, ant-plant interactions, biological control, herbivorous predatory insects

\section{A presença de formigas pode interferir na abundância de artrópodes sobre plantas de milho Zea mays L. (Poaceae)?}

\section{Resumo}

Métodos alternativos ao controle químico de pragas em monoculturas têm sido amplamente avaliados com o intuito de diminuir o uso de agrotóxicos. Neste sentido, a eficiência de artrópodes predadores que agem como controladores de populações nos mais diversos agroecossistemas vem sendo testada. Este estudo objetivou verificar se a presença de formigas interfere na abundância de artrópodes herbívoros e predadores sobre plantas de milho, Zea mays L. (Poaceae). Foram avaliadas 100 plantas, 50 isoladas de formigas e as outras 50 não isoladas. Foram observados 25 taxa de artrópodes sob plantas de milho sendo 14 de herbívoros e 11 de predadores. O livre acesso das formigas às plantas influenciou negativamente a abundância de Diabrotica speciosa (Germar, 1824) (Coleoptera: Chrysomelidae), um importante herbívoro praga da monocultura de milho. Nas plantas com formigas foi também observada maior abundância de Doru sp.1 (Dermaptera: Forficulidae), um importante inimigo natural de pragas em agroecossistemas. A abundância dos demais artrópodes não foi influenciada pela presença das formigas nas plantas avaliadas. Esses resultados sugerem que a interação formiga-planta-herbívoro em monocultura de milho é um sistema complexo, e que a presença de formigas predadoras sob plantas nem sempre interfere na presença de outros artrópodes.

Palavras chave: agroecossistema, controle biológico, herbívoros, insetos predadores, interação formiga-planta 


\section{Introduction}

Many studies have been developed in order to assess the efficiency of predatory arthropods as biological agents for biological control as an alternative method for chemical plague control in monocultures (Carvalho et al., 2013; Paredes et al., 2013;). In this context, ants stand out in this scenario due to their effectiveness as general predators, they influence the structure, composition and dynamics of arthropod communities in different environments (see RicoGray \& Oliveira, 2007). In Europe, some studies have been made in order to assess the potential of ants as agents for biological control in pinus (Neuvonen et al., 2012) and olive orchards (Paredes et al., 2013) reforestation areas. Similar studies have been made in cotton (Kaplan \& Eubanks, 2005; Wickings \& Ruberson, 2011), corn (Knutson \& Campos, 2008), cocoa (Philpott \& Armbrecht, 2006; Tadu et al., 2014), sugar cane (Souza et al., 2010) and orchards (Fernandes et al., 2012) in North and South America.

However, due to its aggressive behavior, ants can prey or repel other natural enemies of herbivorous and it causes negative indirect impact on plants protection against herbivorous (Kaplan \& Eubanks, 2005; Powell \& Silverman, 2010; Wickings \& Ruberson, 2011). Therefore, results from these interactions do not always bring benefits to the involved plants and it shows limitations to the ant-plant interaction (Alves-Silva \& Del-Claro 2016; Lange \& Del-Claro, 2014).

Elements such as ant species features (Byk \& Del-Claro, 2010; Calabuig et al., 2015), their density (De la Mora et al., 2015) and also herbivorous defense strategy against predation (Bächtold \& Alves-Silva, 2013) have been pinpointed as a variance cause in plant-ant interaction results. Such fluctuation indicates that when species are placed inside a network of multitrophic interactions, it becomes harder to predict the ecological dynamics within these relationships (Jones et al., 2009).

Despite the importance of understanding the ecological potential features of generalist predatory insects - as in the case of some predatory ant species - in comparison to other populations, so far, studies are away from covering the whole context in which those interactions happen. These studies may be considered rare, mainly in agro-ecosystem environments, and such fact makes harder to understand the real efficiency of ants as biological plague control agents. Thus, the current study aims to verify if the presence of ants on corn plants influences the amount of herbivorous and other predatory arthropods on these plants. It is expected that not only herbivorous, but also predators, are influenced by the presence of ants on plants; however, some species may be more influenced than others.

\section{Material e Methods}

\section{Studied Area}

The study was conducted in Dourados

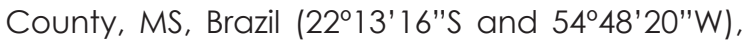
from January to March 2005 in a $3.000 \mathrm{~m}^{2}$ area of Zea mays L. (Poaceae) monoculture, using the no-tillage system. The climate in the area is Cwa (Dry humid subtropical climate, which has humid summer and dry winter) according to the Köppen classification (Fietz \& Fisch, 2008).

\section{Data collection}

In this study were established 10 transects with 10 plants each. Each transect was composed of five plants from the control group, and five from the treatment group, interleaved. All plants were isolated by keeping one meter of distance between plants. In the treatment group plants, a $3 \mathrm{~cm}$ band of TJEATON'S® glve was placed on the main stem, $10 \mathrm{~cm}$ from the soil, to avoid ants foraging upon them. The glve was weekly renewed and always kept in the recommended condition to avoid ants passing on the top of the plants. Ants that were eventually found on the glue-isolated plants were manually removed. Ants were removed from the treatment group after the plants reached $30 \mathrm{~cm}$ height. During the assessment period, no herbicide or insecticide was applied to the studied area.

Data were weekly collected throughout a seven-week period, maintaining 50 plants of the control group (with access to ants) and 50 in the treatment group (without access to ants), totaling 100 sample units. All collections were performed between 04:00 and 06:00 pm. The number of individuals from each arthropod 
species found on the plant was recorded, even the ants on plants in which the removal had not been performed yet. Only one individual of each ant specie/morphospecies was collected and put in alcohol $70 \%$ for further identification. These species samples were stored in the etymological collection of the insect ecology laboratory at Universidade Federal da Grande Dourados (UFGD). Efficiency data of the assessed plants were not collected due to the Psittaciformes infestation that took place days before harvest.

\section{Data analysis}

The mean amount of individuals found on each plant, during the seven assessments, were compared to that of plants with and without ant culture ( $n=50$ to each group of plants). It was done to assess the influence of ants' presence on the amount of arthropods on corn. Subsequently, the arthropod communities were separated in two functional groups - predators (except ants) and herbivorous - and they were also compared to those of plants with and without ants. The
Mann-Whitney test (the $U$ test) was used for these comparisons, since data did not present regular distribution - according to the normality test of Lilliefors, $5 \%$ level. It was also observed a correlation between the amount of herbivorous and predators and the amount of ants in the assessments - plants were the sample units ( $n=50$ to each correlation) and Spearman was used. Results were considered statistically significant whenever they presented probability lower or equal to $5 \%$.

\section{Results}

Ten (10) morphospecies of predatory ants - belonging to seven genus and four subfamilies (Table 1) - were collected during the whole assessment period. Among them, genus Solenopsis and Brachymyrmex were more frequent and represented $78.3 \%$ of ant frequency. The morphospecies Solenopsis sp.1 showed the highest relative frequency (56.6\%) and it was followed by the genus Brachymyrmex sp. 1 (18.9\%) (Table 1).

Table 1. Relative frequency of ant species found on the top of corn plants, Zea mays L. (Poaceae), in Dourados, MS, Brazil, from January to March 2005.

\begin{tabular}{ccc}
\hline Subfamilies & Morphospecies & Relative frequency (\%) \\
\hline \multirow{2}{*}{ Myrmicinae } & Solenopsis sp.1 & 56.6 \\
& Pheidole sp.1 & 9.5 \\
& Pheidole sp.2 & 1.9 \\
& Crematogaster sp.3 & 1.9 \\
Formicinae & Brachymyrmex sp.1 & 18.9 \\
& Brachymyrmex sp.2 & 2.8 \\
Dolichoderinae & Camponotus crassus Mayr, 1862 & 0.9 \\
Pseudomyrmicinae & Camponotus sp.2 & 3.8 \\
\hline Total & Dorymyrmex sp.1 & 2.8 \\
\hline
\end{tabular}

Twenty five (25) arthropod taxa (except ants) were found on the studied plants. Fourteen (14) of them were herbivorous insects that belong to five insect orders: Lepidoptera $(2$ taxa), Hemiptera (6 taxa), Coleoptera (4 taxa), Hymenoptera (1 taxon), and Orthoptera (1 taxon). The other 11 taxa were predators from six insect orders: Hemiptera (4 taxon), Coleoptera (2 taxa), Hymenoptera (1 taxon), Diptera (1 taxon),
Dermaptera (1taxon), Neuroptera (1 taxon), and an order which belongs to the class Arachnida (See the identification of the arthropods on table 2).

Changes were not evident $(U=1188$; $\mathrm{p}=0,671$ - Figure 1) when the mean amount of arthropods (except ants) was compared among plants with and without ants. Plants from the control group (with ants) presented mean 
Table 2. The mean abundance ( \pm standard error) of each arthropod taxon, except for the ants found on the top of plants with and without ants on the monoculture of Zea mays L. (Poaceae), in Dourados, MS, Brazil, from January to March 2005.

\begin{tabular}{|c|c|c|c|c|c|}
\hline \multirow{2}{*}{ Functional groups/Species } & \multirow{2}{*}{ Stage } & \multirow{2}{*}{ Without ants } & \multirow{2}{*}{ With ants } & \multicolumn{2}{|c|}{ Mann-Whitney } \\
\hline & & & & Test-value & p-value \\
\hline \multicolumn{6}{|l|}{ Herbivores } \\
\hline \multirow{2}{*}{ Spodoptera frugiperda (Smith, 1797) } & Adult & - & - & - & - \\
\hline & Larvae & $0.04 \pm 0.014$ & $0.049 \pm 0.019$ & 1245 & 0.964 \\
\hline Helicoverpa zea (Boddie, 1850) & Larvae & $0.063 \pm 0.23$ & $1.1 \pm 0.08$ & 1231 & 0.864 \\
\hline Deois flavopicta (Stal, 1854) & Adult & - & $0.011 \pm 0.006$ & - & - \\
\hline Dalbulus maidis (Delong \& Wolcott, 1923) & Adult & $0.689 \pm 0.095$ & $0.689 \pm 0.093$ & 1243 & 0.964 \\
\hline Rhopalosiphum maidis (Fitch, 1856) & Adult & $15.260 \pm 3.702$ & $9.566 \pm 2.075$ & 1208 & 0.774 \\
\hline \multirow{2}{*}{ Leptoglossus zonatus (Dallas, 1852) } & Adult & $0.077 \pm 0.025$ & $0.046 \pm 0.014$ & 1153 & 0.373 \\
\hline & Nymph & $0.017 \pm 0.008$ & $0.063 \pm 0.024$ & 1140 & 0.210 \\
\hline Euschistus heros (Fabrius, 1794) & Adult & - & $0.003 \pm 0.003$ & - & - \\
\hline Nezara viridula (Linnaeus, 1758) & Adult & $0.003 \pm 0.003$ & $0.014 \pm 0.008$ & 1199 & 0.305 \\
\hline Lagriidae sp. 1 & Adult & - & $0.003 \pm 0.003$ & - & - \\
\hline Sitophilus sp. 1 & Adult & $0.237 \pm 0.37$ & $0.160 \pm 0.036$ & 990.0 & 0.061 \\
\hline Diabrotica speciosa (Germar, 1824) & Adult & $0.171 \pm 0.023$ & $0.100 \pm 0.022$ & 880.0 & $0.006^{*}$ \\
\hline Astylus variegatus (Germar, 1824) & Adult & $0.017 \pm 0.008$ & $0.023 \pm 0.009$ & 1201 & 0.553 \\
\hline Apis mellifera Linnaeus, 1758 & Adult & $0.003 \pm 0.003$ & $0.003 \pm 0.003$ & 1250 & 0.989 \\
\hline Orthoptera sp.1 & Adult & $0.003 \pm 0.003$ & $0.006 \pm 0.004$ & 1225 & 0.568 \\
\hline \multicolumn{6}{|l|}{ Predators } \\
\hline Geocoris sp. 1 & Adult & $0.106 \pm 0.019$ & $0.140 \pm 0.025$ & 1117 & 0.326 \\
\hline Orius sp. 1 & Adult & $0.246 \pm 0.033$ & $0.183 \pm 0.029$ & 1053 & 0.161 \\
\hline Reduviidae spp. & Adult & $0.023 \pm 0.009$ & $0.031 \pm 0.011$ & 1219 & 0.730 \\
\hline Nabis sp. 1 & Adult & $0.011 \pm 0.006$ & $0.017 \pm 0.007$ & 1200 & 0.511 \\
\hline \multirow{2}{*}{ Coccinellidae spp. } & Adult & $0.103 \pm 0.023$ & $0.060 \pm 0.012$ & 1138 & 0.372 \\
\hline & Nymph & $0.037 \pm 0.019$ & $0.006 \pm 0.006$ & 1174 & 0.165 \\
\hline Cycloneda sanguinea (Linnaeus, 1763) & Adult & $0.029 \pm 0.010$ & $0.037 \pm 0.012$ & 1201 & 0.617 \\
\hline Telemonus sp. 1 & Adult & $0.249 \pm 0.036$ & $0.274 \pm 0.045$ & 1248 & 0.989 \\
\hline Syrphidae spp. & Adult & $0.014 \pm 0.006$ & $0.006 \pm 0.004$ & 1175 & 0.245 \\
\hline Doru sp.1 & Adult & $0.754 \pm 0.080$ & $1.023 \pm 0.095$ & 930.5 & $0.027^{*}$ \\
\hline Chrysopidae spp. & Nymph & $0.011 \pm 0.011$ & $0.009 \pm 0.005$ & 1202 & 0.330 \\
\hline Araneae & Adult & $0.046 \pm 0.010$ & $0.026 \pm 0.009$ & 1079 & 0.107 \\
\hline
\end{tabular}

arthropods amount $18.21 \pm 3.708$ ( \pm standard error) and plants from the treatment group (without ants) presented $12.59 \pm 2.072$. Changes were also not evident $(U=1160 ; p=0.537$ Figure 2a; $U=1053 ; p=0.174$ - Figure 2b) when the average of herbivorous and other predators were compared among plants with and without ants. However, plants without ants had almost twice more herbivorous than plants with ants (116.04 $\pm 25.89,75.42 \pm 14.49$, respectively). On the other hand, the average of predators was similar between plants with and without ants $(12.68 \pm 0.66 ; 11.10 \pm 0.80$, respectively). 


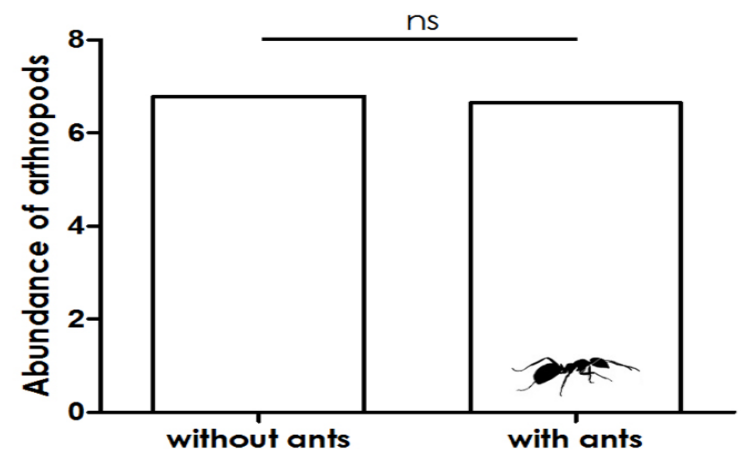

Figure 1. Mean abundance median of arthropods found on plants with and without ants in the monoculture of Zea mays L. (Poaceae), in Dourados, MS, Brazil, from January to March 2005. $(U=1188 ; p=0.671)$

(a)

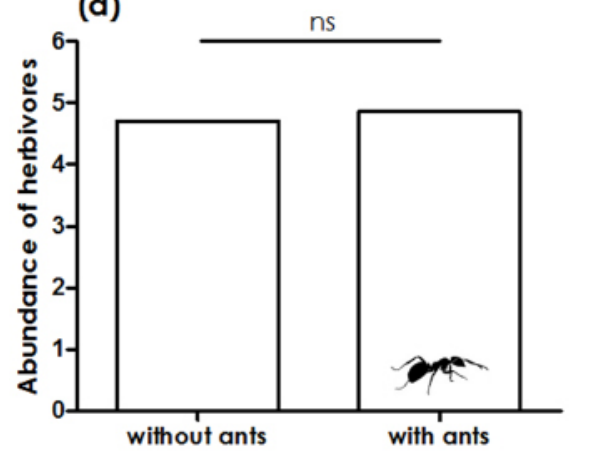

(b)

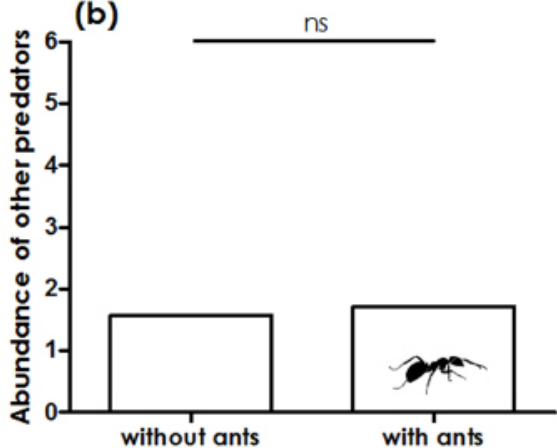

Figure 2. Mean abundance median of herbivorous (a) and of other predators (b) found on plants with and without ants in the monoculture of Zea mays L. (Poaceae), in Dourados, MS, Brazil, from January to March 2005.

$(U=1160 p=0,537$ - Figure $2 a ; U=1053 p=0,174$ - Figure $2 b)$

A non-significant and negative connection was observed $\left(R_{s}=-0.1635 p=0.256\right)$ between mean abundance of herbivorous and ants on plant with ants. A similar result was presented when the connection between the mean abundance of other predators and ants on plants with ants was assessed $\left(R_{s}=-0.1981 p=\right.$ $0.172)$.

When the mean abundance of each taxon was separately compared among plants with and without ants, the species Diabrotica speciosa (Germar, 1824) (Coleoptera: Chrysomelidae) was the only one from the functional group of herbivorous that presented significantly different values among the plant groups (see Table 2). Therefore, plants with ants presented greater abundance of D. speciosa individuals than plants without them.

Trophobiosis cases between Hemiptera species and ants were observed during the study performance. The following hemipterous presented such behavior: Deois flavopicta (Stal, 1854) (Hemiptera: Cercopidae), Dalbulus maidis (Delong \& Wolcott, 1923) (Hemiptera: Cicadellidae) and Rhopalosiphum maidis (Fitch,
1856) (Hemiptera: Aphididae). Nevertheless, changes in the mean abundance of these organisms among plants with and ants were not noticed (see Table 2).

Among the taxa in the group of predators, Doru sp.1 (Dermaptera: Forficulidae) was the only one that presented abundance levels significantly different among plants with and without ants. Thus, a greater abundance of that specie was observed on plants with ants.

\section{Discussion}

Only two species of arthropods (Diabrotica speciosa and Dorus sp.1) were negatively influenced by the presence of ants on plants of Z. mays. The herbivorous D. speciosa was found in greater abundance in plants without ants. According to Kalsi et al. (2014), D. speciosa is a polyphagous insect that is considered to be a plague in monocultures with great economic importance, such as corn, soy, bean and rice. Diabrotica speciosa adults basically feed on leaves and stand on the ground. The larvae damage the root system of the plants and affect the absorption of water and nutrients (Marodim et al., 1998). According to the results of this 
study, individuals from this herbivorous species prefer plants without ants or, on the other hand, ants would be preying these herbivorous on corn plants. Regardless the presented result, it is possible to assert that, in this case, ants that patrol the corn plants work as theirs plants' protectors and it leads to decrease in the presence of $D$. speciosa on them.

The current study also confirmed that plants with ants had higher mean abundance of the predatory species Doru sp.1. This result may be due to generalist habits of species of the order Dermaptera. Similarly to ants, Dermaptera species also are predators. Therefore, the presence of ants may have attracted Dermaptera individuals to plants of control group. Even though there was not an evidence of ants predation by Dorus sp.1 individuals, the presence of these two predator groups on plants may have caused stress on both. In contrast, the presence of these predators or their free access to plants may have increased the protection of these plants against herbivorous. According to Figueiredo et al. (2006), in a study performed with Dorus luteipes (Scudder, 1876) (Dermaptera: Forficulidae), these insects may be important Spodoptera frugiperda infestation (J.E. Smith, 1797) (Lepidoptera: Noctuidae) an important plague in corn culture - controller when they are put together with other predators. Other study showed that Dermaptera of genus Dorus are efficient herbivorous predators in corn monoculture (see Cruz 1991). Additionally, Buschman et al. (1977) observed that Formicidae and Dermaptera were the most frequent predators on plants in soy monocultures. Both predators worked as plague insect population controllers. Therefore, according to authors, some predator species - as those in the genus Dorus - may be influenced by the presence of ants. However, further studies should be performed in order to verify the predation taxa among these two predator groups (Formicidae and dermapterous of genus Dorus).

According to the present study, the mean abundance of herbivorous on plants with ants was higher in comparison to plants without ants, although this difference was not significant. Therefore, ants helped to decrease the amount of herbivorous on corn plants evaluated in this study. This result can be applied to the herbivorous Rhopalosiphum maidis and Sitophilus sp.1 besides $D$. speciosa, as mentioned before. On the other hand, predatory arthropod communities in general were not influenced by the presence of ants on the plants. However, some species such as Orius sp.1 and Coccinelidae spp. presented higher mean abundance on plants without ants. Dorus sp.1 presented higher abundance on plants with ants, as it was previously mentioned. Such results showed the uniqueness among species in the same guild.

Evident negative correspondence was not shown among ants, herbivorous and the amount of predators on plants. These results show that the abundance of ant species found on the studied plants was not a key factor to influence the presence of other arthropods. Likely, other factors, such as species identity, herbivorous and predators - and their predation and defense strategies - may have been important.

Some studies have shown that the result of ant-plant interaction is dependent of the species of predatory ants involved interaction (Byk \& Del-Claro, 2010; Calabuig et al., 2015) and of the strategies of herbivorous against predation (Bächtold \& Alves-Silva, 2013; Carita et al., 2006; Styrsky \& Eubanks, 2010). Nevertheless, little is known about the behavior between pairs (predator-prey) determining plant protection.

The two most frequent ant species on plants in the current study were Solenopsis sp. 1 and Brachymyrmex sp.1. The first one belongs to a genus of efficient predatory ants (Styrsky et al., 2006). However, according to Silvestre et al. (2003), the foraging activity of the species Solenopsis happens under the soil. This species belongs to a guild of soil dominant omnivorous. In contrast, species of the genus Brachymyrmex belong to an opportunistic guild on the soil and on the vegetation. Species in this genus do not present dominant aggressive behavior regarding food resources (Silvestre et al., 2003). Other ant species found in the present study presented frequency lower than $10 \%$. It may reflect Solenopsis prevalence on soil and on the plants, it may have prevented that other ant species from climbing on the plants. The aggressiveness of ant 
species, such as Solenopsis genus may generate hierarchy dominance, when some ant species dominate over others. This scenario create the ant mosaic (sensu Ribeiro et al., 2013), and it is considered to be one of the basic factors for ant communities (Blight et al., 2014).

\section{Conclusion}

According to the results, is possible to observe the complexity of the ant-plantherbivore interaction. Although not significant, the mean herbivorous abundance on plants without ants was high. On the other hand, many herbivorous were not influenced by the absence of ants on the plants. A similar result was shown for predatory arthropods and some of them may have been attracted by the presence of ants. Therefore, the complexity for this multitrophic interaction does not allow to state that ants are efficient agents for biological control. Further studies on this pair-to-pair interaction among the species involved in these process need to be performed to better understand the features and behaviors of these species that could influence the results of these ecological connections.

\section{Acknowledgements}

The authors would like to thank the Brazilian National Council for Scientific and Technological development (CNPq), for the scholarships for the first author (O. S. Gossler process 134235/2004-5).

\section{References}

Alves-Silva, E., Del-Claro, K. 2016. On the inability of ants to protect their plant partners and the effect of herbivores on different stages of plant reproduction. Austral Ecology 41: 263-272.

Bächtold, A., Alves-Silva, E. 2013. Behavioral strategy of a lycaenid (Lepidoptera) caterpillar against aggressive ants in a Brazilian savanna. Acta Ethologica 16: 83-90.

Blight, O., Orgeas, J., Torre, F., Provost, E. 2014. Competitive dominance in the organization of Mediterranean ant communities. Ecological Entomology 39(5): 595-602.

Buschman, L.L., Whitcomb, W.H., Hemenway, R.C., Mays, D.L., Ru, N., Leppla, N.C., Smittle, B.J. 1977. Predators of velvet bean caterpillar eggs in Florida soybeans. Environmental Entomology 6: 403-407.

Byk, J., Del-Claro, K. 2010. Nectar-and pollen- gathering Cephalotes ants provide no protection against herbivory: a new manipulative experiment to test ant protective capabilities. Acta Ethologica 13(1): 33-38.

Calabuig, A., Garcia-Marí, F., Pekas, A. 2015. Ants in citrus: impact on the abundance, species richness, diversity and community structure of predators and parasitoids. Agriculture, Ecosystems and Environment 213: 178-185.

Carita, L., Johanna, M., Jussi, P., Martti, V. 2006. Effects of group size and pine defense chemicals on Diprionid sawXy survival against ant predation. Oecologia 150: 519-526.

Carvalho, M.M., Bueno, R.C.O.F., Carvalho, L.C., Favoreto, A.L., Godoy, A.F. 2013. Potencial do controle biológico para o controle de Pseudoplusia includens (Walker, 1857) e Anticarsia gemmatalis Hübner, 1818 (Lepidoptera: Noctuidae) em soja. Enciclopédia Biosfera. Centro Científico Conhecer 9(17): 2049-2063.

Cruz, I. 1991. Potencial de Doru luteipes como predador de spodoptera frugiperda em condições de campo. Relatório Técnico Anual do Centro Nacional de Pesquisa de Milho e Sorgo 4: 85-86.

De la Mora, A., García-Ballinas, J.A., Philpott, S.M. 2015. Local, landscape, and diversity drivers of predation services provided by ants in a coffee landscape in Chiapas, Mexico. Agriculture, Ecosystems and Environment 201: 83-91.

Fernandes, W.D., Sant'Ana, M.V., Raizer J., Lange, D. 2012. Predation of fruit fly larvae Anastrepha (Diptera: Tephritidae) by ants in grove. Psyche ID 108389.

Fietz, C.R., Fisch, G.F. 2008. O Clima da Região de Dourados, MS. Embrapa (MS), Documentos 92, $2^{a}$ edição. $32 \mathrm{p}$.

Figueiredo, M.L.C., Dias, A.M.P.M., Cruz, I. 2006. Associação entre inimigos naturais e Spodoptera frugiperda (Smith, 1797) (Lepidoptera: Noctuidae) na cultura do milho. Revista Brasileira de Milho e Sorgo 5(3): 340-350.

Jones, E.I., Ferriere, R., Bronstein, J.L. 2009. Eco-evolutionary dynamics of mutualists and exploiters. American Naturalist 174: 780-794.

Kaplan, I., Eubanks, M.D. 2005. Aphids alter the community-wide impact of fire ants. Ecology 86(6): 1640-1649.

Kalsi, M., Seal, D.R., Nuessly, G.S., Capinera, J.L., Martin, C.G. 2014. Seasonal timing, abundance, and predatory status of arthropods associated with corn infested by picture-winged flies (Diptera: Ulidiidae) in south Florida. Florida Entomologist 97: 168-178. 
Knutson, A.E., Campos, M. 2008. Effect of red imported fire ant, Solenopsis invicta on abundance of corn earworm, Helicoverpa zea, on Maize in Texas. Southwestern Entomologist 33: 1-13.

Lange, D., Fernandes, W.D., Raizer, J., Faccenda, O. 2008. Predacious activity of ants (Hymenoptera: Formicidae) in conventional and in no-till agriculture systems. Brazilian Archives of Biology and Technology 51 (6): $1199-1207$.

Lange, D., Del-Claro, K. 2014. Ant-plant interaction in a tropical savanna: may the network structure vary over time and influence on the outcomes of associations? PIOS ONE 9(8): e105574.

Marodim, V.S., Costa, E.C., Thum, A.B., Ohse, S. 1998. Plantio direto e sua influência na população faunística nas culturas de Oriza sativa e Zea mays. Revista da FZVA Uruguaiana 5: 90100.

Neuvonen, S., Saikkonen, T., Sundström, L., Punttila, P., Risch, A.C., Domisch, T., Niemelä, P., Kilpeläinen, J., Ohashi, M., Finér, L. 2012. Stand type is more important than red wood ant abundance for the structure of ground-dwelling arthropod assemblages in managed boreal forests. Agricultural and Forest Entomology 14: 295-305.

Paredes, D., Cayuelab, L., Camposa, M. 2013. Synergistic effects of ground cover and adjacent vegetation on natural enemies of olive insect pests. Agriculture, Ecosystems and Environment 173: $72-80$.

Philpott, S.M., Armbrecht, I. 2006 Biodiversity in tropical agroforests and the ecological role of ants and ant diversity in predatory function. Ecological Entomology 31: 369-377.

Powell, B.E., Silverman, J. 2010. Impact of Linepithema humile and Tapinoma sessile (Hymenoptera: Formicidae) on three natural enemies of Aphis gossypii (Hemiptera: Aphididae). Biological Control 54: 285-291.

Ribeiro, S.P., Espírito Santo, N.B., Delabie, J.H.C., Majer, J.D. 2013. Competition, resources and the ant (Hymenoptera: Formicidae) mosaic: a comparison of upper and lower canopy. Myrmecological News 18: 113-120.

Rico-Gray, V., Oliveira, P.S. 2007. The ecology and evolution of ant-plant interactions. University of Chicago Press. 331 p.

Silvestre, R.C.R.F., Brandão, C.R.F., Rosa da Silva, R. 2003. Grupos funcionales de hormigas: el caso de los gremios del cerrado. In: Fernandez, F. (ed.) Introducción a las hormigas de la región neotropical. Bogotá: Instituto de investigación de recursos biológicos Alexander von Humboldt.

\section{p. 101-136}

Souza, D.R., Stingel, E., Almeida, L.C., Lazarini, M.A., Munhael, C.B., Bueno, O.B., Archangelo, C.R., Morinil, M.S.C. 2010. Field methods for the study of ants in sugarcane plantations in Southeastern Brazil. Scientia Agricola 67(6): 651657.

Styrsky, J.D., Kaplan, I., Eubanks, M.D. 2006. Plant trichomes indirectly enhance tritrophic interactions involving a generalist predator, the red imported fire ant. Biological Control 36: 375384.

Styrsky, J.D., Eubanks, M.D. 2010. A facultative mutualism between aphids and an invasive ant increases plant reproduction. Ecological Entomology 35: 190-199.

Tadu, Z., Djiéto-Lordon, C., Youbi, E.M., Aléné, C.D., Fomena, A., Babin, R. 2014. Ant mosaics in cocoa agroforestry systems of Southern Cameroon: influence of shade on the occurrence and spatial distribution of dominant ants. Agroforestry Systems 88: 1067-1079.

Wickings, K.G., Ruberson, J. 2011 . Impact of the red imported fire ant (Hymenoptera: Formicidae) on epigeic arthropods of cotton agroecosystems. Annals of the Entomological Society of America 104(2): 171-179. 